\title{
ЯЗЫКОВАЯ СИТУАЦИЯ \\ И ЯЗЫКОВАЯ ПОЛИТИКА В РОССИИ (РЕВИЗИЯ КАТЕГОРИЙ И ПРАКТИК)
}

\section{B.А. Тишков}

ТИШКОВ Валерий Александрович, доктор исторических наук, профессор, академик РАН, научный руководитель, Институт этнологии и антропологии РАН; главный научный сотрудник Учебно-научного центра социальной антропологии, Российский государственный гуманитарный университет, Москва, email: valerytishkov@mail.ru

Тишков В.А. Языковая ситуация и языковая политика в России (ревизия категорий и практик). Полис. Политические исследования. 2019. № 3. С. 127-144. https://doi.org/10.17976/jpps/2019.03.08

Статья подготовлена при поддержке Российского научного фонда (проект № 14-18-03090).

Статья поступила в редакцию: 08.12.2018. Принята к печати: 19.01.2019

Аннотация. В статье рассматривается практика категоризации и процедур в сфере языковых ситуаций и языковой политики в России в сравнительном аспекте. В центре анализа взаимосвязи “язык и этничность”, “язык и политика”, особенно в практике переписей населения, и их интерпретации. Предлагается пересмотр категорий “родной язык”, “материнский язык”, “национальный язык” в пользу ситуативного и множественного подходов, которые учитывают факторы рационального выбора, языкового рынка, структурных предписаний, языкового репертуара в культурно-сложных обществах, а также историческую динамику языковых процессов. Автор обосновывает отсутствие жесткой связи между языком и этничностью и ставит вопрос обеспечения прав языковых сообществ, поддержки языков как самостоятельных ценностей в культуре человеческих коммуникаций. В сфере языковой политики рассматриваются роль языковых проблем в современном нациестроительстве, соотношение государственного (национального) языка и этнических (миноритарных) языков в общественной жизни таких стран, как Российская Федерация.

Ключевые слова: Россия, родной (материнский) язык, государственный (национальный) язык, языковая ситуация, языковая политика, национальность, этничность, перепись населения, нациестроительство, языковые права, школьное образование.

\section{ВВЕДЕНИЕ}

Становится все более очевидным, что многие прогнозы социолингвистов и антропологов о скором вымирании большинства существующих в мире языков под воздействием глобализации оказываются ошибочными. Скорее профилактической по своему воздействию и политически мотивированной была и остается возглавляемая ЮНЕСКО масштабная кампания в защиту “находящихся в опасности” языков ${ }^{1}$. К этому же разряду можно отнести и ряд международных деклараций и программ, среди которых наиболее значимой является Европейская хартия региональных языков и языков национальных меньшинств. Наши исследования показывают, что современные нации становятся все больше культурно-сложными сообществами, а их языковое

\footnotetext{
${ }^{1}$ Атлас мировых языков, находящихся под угрозой исчезновения. 2001. URL: http://www.unesco.org/ languages-atlas/index.php?hl=en\&page=atlasmap (accessed 01.04.2019).
} 
многообразие не уменьшается, а даже увеличивается. Нет убедительных данных и о том, что общее число языков в мире катастрофически уменьшается, а на территории бывшего СССР (прежде всего РФ) языковая номенклатура и жизненность языков (использование языков, языковые компетентность и лояльность) имеют далеко не отрицательную динамику [Культурная сложность... 2016; Решение... 2017; Этническое и религиозное многообразие... 2018]. Все это актуализирует потребность в анализе языковых ситуаций.

Язык представляет собой многоаспектный социально-исторический феномен, а языковое взаимодействие - это сложнейшая практическая деятельность, которая протекает в собственном габитусе и одновременно взаимодействует с несколькими “полями власти". Язык - это власть, которая реализуется не столько через прямое насилие, сколько через субъективные предписания (индоктринацию): семейные установки, систему образования, медиа, научно-бюрократические классификации, языковую политику, включая правовые нормы [Бурдьё 2005; Scwartz 1998; Myles 2010].

В зарубежной литературе имеются многочисленные исследования языковой политики и политики языка в разных регионах и странах [Laitin 1998; Gorenburg 2003; Grenoble 2003; Hirsch 2005; Chevalier 2005; Gorham 2014]. Что касается российской ситуации после распада СССР, то здесь, несмотря на некоторые устаревшие подходы, ведущие позиции занимают отечественные социолингвисты и антропологи. Из последних публикаций отметим энциклопедическое издание, подготовленное в Институте языкознания РАН [Язык и общество... 2016], а также другие коллективные издания [Языковая политика в контексте... 2015; Решение национально-языковых вопросов... 2017; Языковая политика, конфликты и согласие... 2017; Языковое единство... 2018]. В политологии тема языковой политики освещена более скромно, если не считать активно разрабатываемые проблемы языка политики и так называемой политической лингвистики.

В центре нашего анализа находится современная российская ситуация и отечественный опыт языковой политики, к которой я и мои коллеги обращались неоднократно с середины 1990-х годов [Губогло 1998; Европейская хартия... 2012; Тишков 2013; Этническое и религиозное многообразие России 2018]. В последние два года одним из центральных в общественном дискурсе оказался вопрос о родных языках и языковых правах в сфере образования. Последние дебаты вокруг языка расширили поле языковой политики. Обычно под этим имеется в виду совокупность принципов, практик и институтов по решению языковых проблем в государстве и обществе. Аналогами этого понятия являются широко используемые термины “языковое планирование" или “языковое строительство". Однако некоторые авторы считают такую трактовку редукцией, игнорирующей практики и действия других акторов в поле языковой политики. Как пишут С.В. Соколовский и Е.И. Филиппова, “любая инициированная правительством или национальной элитой языковая реформа поляризует мнения граждан, которых невозможно рассматривать лишь как пассивных реципиентов этой реформы: она не будет иметь успеха без поддержки населения и, таким образом, даже следование ее целям и принципам, не говоря уже о противодействии и протестах, должно рассматриваться тоже как политическое действие, направленное на реализацию конкретной стратегии языкового планирования" [Языковая политика, конфликты и со- 
гласие 2017: 5]. Российский и зарубежный опыт показывают, как в обсуждение языковых вопросов вовлекаются самые разные сообщества (образовательные, научные, городские, сельские, диаспорные), институты гражданского общества (профессиональные ассоциации, медиа, этнокультурные организации и объединения и т.д.). Поэтому резонно включать в понятие языковой политики "не только макроуровни международной и государственной политики в области языка, но также и мезо- (цели, программы, действия региональных элит) и микроуровень (локальные или низовые стратегии носителей языка, способных не только поддерживать или отвергать инициативы, исходящие из двух выше названных уровней, но и реализовывать собственные)" [там же: 6].

Это широкое обозначение языковой политики фактически утвердилось в мировой науке. Недавняя международная конференция, организованная Институтом языкознания РАН, также продемонстрировала широкий спектр подходов российских исследователей к этой теме [Языковое единство... 2018]. Наиболее существенную проблему я вижу в теоретико-гносеологических подходах и в той базовой терминологии, которая досталась нам от периода советского “национально-государственного строительства". Пересмотр или корректировку некоторых базовых категорий и сопутствующих им практик мы предлагаем ниже.

\section{1. ОПЫТ ЯЗЫКОВЫХ КАТЕГОРИЙ И ИХ РЕВИЗИЯ}

Применительно к отдельной личности выбор языка и языковое поведение отличаются рациональными мотивами индивида, хотя изначально они, конечно, во многом определяются условиями семейной и общественной среды, а среди последних факторов большую роль играют ценностные и политико-правовые предписания. Рациональность и среда связаны неразрывно, но на разных жизненных этапах их воздействия различны. Обычно человек усваивает свой первый выученный в детстве язык от родителей, чаше всего от матери, и поэтому этот язык, если его знание сохраняется по жизни, называют материнским языком (langue maternal, mother tongue). В большинстве случаев этот язык остается для человека основным языком знания и общения на всю его жизнь. Именно этот основной (или первый) язык и считается родным языком, если вообще такая категория анализа и практики используется в том или ином обществе и в научной среде.

Так, например, международная языковая статистика и управленцы-регуляторы большинства стран, где проводятся переписи населения, не пользуются понятием “родной язык” в силу его многозначности и эмоциональной ангажированности. Существенные сомнения в отношении этой категории высказывают и некоторые российские ученые [Алпатов 2000 ], которые мы разделяем. В зарубежной научной среде эта категория используется чаще всего при описании языковой ситуации среди аборигенного населения стран Америки. Но в этих же странах и в англоязычной научной периодике известен журнал “Первый язык” (First Language), издающийся с 1980 г. в Лондоне.

Российские социолингвисты признают многозначность данной категории. Социолингвистический словарь и энциклопедия приводят четыре значения “родной язык”: материнский язык (“язык колыбели”); этнический язык (язык национальности независимо от владения); функционально первый язык (основной язык знания и пользования); то же, что и этнический (как язык любого народа РФ, кроме русского). Последняя трактовка представляется аб- 
сурдной, хотя и была в обиходной практике и даже в научном языке до самого последнего времени (например, выражение “школы с родным языком обучения и школы с русским языком обучения”). Вступивший в силу с 1 сентября 2018 г. Федеральный закон № 273 “Об образовании в Российской Федерации” частично исправил эту ситуацию, признав за русским языком право также считаться "родным языком". Но из текста федерального правового акта следует, что это относится только к ученикам русской национальности, ибо используется концепт “язык народа"! Пункт 4 статьи 14 закона изложен следующим образом: “Граждане Российской Федерации имеют право на получение дошкольного, начального общего и основного общего образования на родном языке из числа языков народов Российской Федерации, а также право на изучение родного языка из числа языков народов Российской Федерации, в том числе русского языка как родного языка, в пределах возможностей, предоставляемых системой образования, в порядке, установленном законодательством об образовании... Преподавание и изучение родного языка из числа языков народов Российской Федерации, в том числе русского языка как родного языка, в рамках имеющих государственную аккредитацию образовательных программ осуществляются в соответствии с федеральными государственными образовательными стандартами, образовательными стандартами”.

Как представляется, размытость формулировок закона приводит к амбивалентной политике. Во-первых, не понятно само выражение “языки народов Российской Федерации”. Видимо, чтобы отсеять “западные” языки или языки других стран. Однако напомним, что среди 193 российских народов значатся американцы, британцы, немцы, испанцы, итальянцы, французы, чехи, японцы и еще пара десятков подобных им “народов”. В этом же списке российских национальностей азербайджанцы, армяне, белорусы, грузины, украинцы и другие, составляющие одновременно основное население других стран бывшего СССР. Причем некоторые из них - это автохтонное население России, и они никак не могут быть отнесены к группам иммигрантского происхождения. Добавим к названным российским автохтонам еще и болгар, греков, казахов, туркмен, поляков и других, живущих в России столетиями. Попытки разделить россиян на категории "коренных" и "некоренных" несостоятельны еще и по причине конституционного равенства граждан страны. Таким образом, сами понятия "из числа народов" или "из числа языков" Российской Федерации являются некорректными.

Однако самая большая проблема - это смысловое содержание категории “родной язык”, которое, видимо, законодателям представлялось настолько ясным, что оно даже не было включено в перечень основных понятий, который сопровождает текст закона. А это большой и больной вопрос для российской политической и культурной жизни. К тому же вслед за законом был издан президентский указ о создании государственного Фонда поддержки и развития родных языков. Какие языки и какие их носители должны будут получать эту поддержку, зависит в том числе и от экспертной проработки вопроса, которой явно не хватало при принятии закона.

Почему категория “родной язык” считается уязвимой для научного анализа и для практики языковой политики? Прежде всего, потому что во многих случаях, особенно в обществах с распространенными этнически смешанными браками, дети с самого детства осваивают два и даже более языков, т.е. 
являются двуязычными. Какой в данном случае язык - отца или матери считать родным, установить трудно, ибо оба языка могут считаться родными. Возникает серьезная коллизия, так как российская наука и практика исходят из того, что родной язык должен быть только один! Многие ученые считают, что родным следует считать язык матери [Шахнарович 1999: 18] и что поэтому не может быть двух родных языков, как не может быть двух матерей. По словам известного лингвиста В.Г. Костомарова, “выученный язык... может стать в жизни человека важнее родного, который, однако, и при забвении остается матерью, пусть и менее любимой, чем мачеха” [Костомаров 1991: 11]. Эти эмоционально окрашенные высказывания расходятся с жизненной практикой.

В понятие родного языка полезно включить аспекты подвижности и ситуативности. В ряде регионов России человек с детства или с молодости владеет и пользуется свободно двумя языками как равными и отдает предпочтение тому или иному языку в зависимости от ситуации или от места нахождения. Приезжая в отпуск в родное село к родителям и родственникам, он быстро погружается в одну языковую среду и даже начинает думать на этом языке (некоторые считают это важным признаком именно родного языка). Затем, возвратившись в город к своей семье и работе, человек переходит на другой язык, который преобладает в данном месте. Примерно так же ситуативно переключается языковое поведение человека, у которого различаются язык домашнего общения и язык работы. Неслучайно в программах переписей населения и в социолингвистических исследованиях часто используются категории “язык домашнего общения" (language spoken at home) и “язык работы” (language at work). А уже затем специалистами выполняется анализ языковых тенденций среди той или иной общности или в стране в целом.

Наконец, существенное неудобство с категорией “родной язык” в ее узком понимании (как материнский и как единственный) - это разрыв с реально существующим как норма многоязычием людских сообществ, в том числе и среди этнических групп. По словам Н.Б. Вахтина, “на Земле около 2/3 населения с рождения дву- или многоязычны: одноязычие - это скорее отклонение от нормы; большинство двуязычных носителей живет в двуязычных сообществах, то есть - ежедневно и ежечасно использует два и более языка в повседневном общении" [Вахтин 2018: 38]. В данном случае имеется в виду такое широко распространенное явление, как языковое взаимодействие и взаимопроникновение, когда в речевой практике используются компоненты разных языков, когда в каждый данный момент человек говорит на одном языке и вставляет в него части из другого. С учетом этого можно сказать, что и в России значительная часть населения является дву- или многоязычной. Прежде всего, это касается так называемого русско-украинского пограничья, где русские и украинцы говорят на смеси двух языков или переходят с одного на другой в повседневной речевой практике [Чижикова 1988], а также нерусского населения таких многоязычных регионов, как Северный Кавказ, Поволжье, южная Сибирь.

Как представляется, для выяснения реальной языковой ситуации, определения переписных процедур и правовых норм, необходимы коррективы категории “родной язык”. Первое: можно предложить расширить само понятие и сделать его более контекстным, т.е. спрашивать в переписи не просто “Ваш родной язык?”, а “Ваш первый выученный язык, знание которого сохраняется?” или “Ваш родной (материнский, первый) язык”? Для корректности лучше спрашивать не материнский, а “родительский" язык, ибо в некоторых сообществах 
(например, среди народов Северного Кавказа) язык отца воспринимается и осваивается детьми в болышей степени, чем язык матери. По крайней мере, по нашим полевым наблюдениям, в этом регионе с выраженной патрилинейностью в системе родства дети смешанных браков родным языком чаще называют отцовский, а не материнский. Безусловно, необходимо позволить россиянам указывать не один, а два языка в этой категории. Ряд стран, где задается такой вопрос в ходе переписей, уже сделали такие поправки (например, Венгрия, Чехия и Литва). Материалы Сети этнологического мониторинга показывают, что часть россиян допускает возможность иметь два родных языка и готова указывать это при переписи населения или других процедурах [Степанов 2018а: 15-18].

Следует признать, что демонтаж категории “родной язык” или даже ее частичная ревизия обязательно встретят трудности. Прежде всего, это аура языкового национализма, при которой метафора родного языка несет огромную нагрузку. Целые поколения отечественных обществоведов, прежде всего лингвистов, выросли с этим обозначением, которое заключает в себе мощный этногрупповой смысл, о чем речь пойдет ниже.

Напомним, что “родной язык” в международном контексте используется чаще как материнский язык и только в редких случаях обозначение "native (indigenous) language" используется в отношении языков аборигенных групп населения. Именно так обозначена эта категория в переписных листах Австралии, Бразилии, Мексики, ряда африканских стран. Так же обозначаются в литературе и в обследованиях индейские языки в США и Канаде. В других случаях категория “родной язык” в привычном для нас смысле (как единственная и совпадающая с этничностью) в большинстве стран мира не используется. Многие страны имеют в переписных листах категорию "материнский язык” (Албания, Армения, Беларусь, Болгария, Молдова, Индия, Хорватия и другие). Неслучайно в 1999 г. ЮНЕСКО объявило 21 февраля памятной датой и назвало ее Международным днем материнского языка (International Mother Language Day) ${ }^{2}$. В России все мероприятия по этой линии были названы по-другому, включая и объявление 2018 г. Годом родных языков.

Отметим, что перед всероссийской переписью населения 2002 г. нам удалось убедить РОССТАТ убрать из проекта программы переписи вопрос о родном языке, заменив его вопросами о владении и использовании. Это вызвало отрицательную реакцию части ученых и общественных активистов, особенно в российских республиках. Тогдашний зам. директора Института этнологии и антропологии РАН М.Н. Губогло опубликовал в "Независимой газете" эмоциональную статью под названием “Кто отнял родной язык?” [Губогло 2018], за которой последовала череда высказываний в пользу сохранения категории “родной язык”. Уже в напечатанный миллионными тиражами переписной бланк было внесено дополнительное указание для переписчиков задавать также вопрос о родном языке и делать соответствующую пометку. Аварийным путем собранные данные не стали адекватным отражением ситуации, которая обычно фиксировалась этим вопросом в наших переписях.

А вот что отражали ответы на вопрос о родном языке в предыдущих советских и в последующих переписях - этот вопрос заслуживает критического разбора, ибо здесь имела место давняя неадекватность интерпретации.

\footnotetext{
2 Эта дата была избрана в память о погибших в 1952 г. студентах-демонстрантах в г. Дакке (ныне это столица Бангладеш), которые выступали за признание языка бенгали государственным языком тогдашней Индии.
} 
Неадекватность была в том, что данные о родном языке трактовались в работах по проблемам распространения двуязычия в СССР без должного учета реального владения так называемыми национальными языками (см., например [Современные этнические процессы... 1975; Губогло, Бромлей 1984]). Сама формулировка вопроса “Ваш родной язык?” не предполагала (и не предполагает поныне) его обязательного знания!

Еще одна неадекватность прошлой практики заключалась в том, что вопрос о языке имел прямую проекцию в этничность. Связь “язык и этнос" появилась в языковедческой науке еще в начале XX в., когда утвердилось мнение швейцарского лингвиста Фердинанда де Соссюра, что "общность языка создает этническое единство”, а язык и этнос пребывают в неразрывном единстве. В этой парадигме трудились многие известные советские исследователи, как лингвисты (В.И. Абаев), так и этнографы (Ю.В. Бромлей, В.И. Козлов, С.А. Арутюнов и другие). Сохраняются сторонники этой жесткой схемы и сегодня, в том числе и среди зарубежных коллег. Так, на международной конференции “Языковое единство и языковое разнообразие в полиэтничном государстве” японский исследователь Танака Кацухико высказался, что “нельзя забывать, что человек - существо 'этническое', и именно язык определяет эту сущностную характеристику человека” [Языковое единство... 2018: 52]. Схожие позиции выразили и авторы других докладов. Попробуем разобраться в этом аспекте языковой политики.

\section{2. “НАЦИОНАЛЬНЫЙ ЯЗЫК” КАК ПРИЗНАК ЭТНОСА?}

Итак, мы установили коллизию в оценке российской языковой ситуации с мировой наукой и общественной практикой: в России чаще всего родным называют не "основной язык знания и общения" (согласно словарю толкового русского языка С.И. Ожегова) и даже не первый выученный язык, а язык собственной этнической принадлежности. Например, как полагает Е.О. Хабенская, "родной язык" - это язык той этнокультурной общности, с которой ассоциирует себя индивид, т.е., строго говоря, “материнский язык” [Хабенская 2004]. Такой же позиции придерживаются многие ученые и практики языковой политики [Ибрагимов, Зачесов 1990; Козлов 1995: 157; Мамардашвили 1992]. Особо рьяно ее защищает титульная общественность в российских республиках, а также представители таких дисциплин, как этнопсихология [Исламшина 1996]. Приведу один из примеров собственных полевых наблюдений. В 1990 г., после переписи населения СССР, во время пребывания в Усть-Ордынском Бурятском автономном округе я беседовал с двумя местными взрослыми бурятами и спросил, какой язык они указали в качестве родного. Те удивленно ответили: "Конечно, бурятский, мы на нем немного говорим”. “А что записали своим детям?” - спросил я. “Тоже бурятский, хотя они совсем не знают родной язык".

Сентенция “не знать родной язык” может потрясать своей несуразицей, но только не российских этнологов и социолингвистов, а тем более политика или общественного активиста. В российском дискурсе эта категория была прочно склеена с категорией национальности, хотя, кстати, в инструкциях переписчикам еще с советских времен было записано, что "родной язык может не совпадать с национальностью". Фактически же на протяжении десятилетий

\footnotetext{
${ }^{3}$ Так было в первой советской переписи 1920 г., а при всеобщей переписи населения 1926 г. инструкция для переписчиков гласила: "Родным языком признается тот, которым опрашиваемый лучше всего владеет или на котором обыкновенно говорит”, т.е. не было увязки с национальностью. Далее,
} 
вопрос о родном языке в переписях населения представлял собой своего рода контрольный вопрос о национальности. Тем более что он и следовал в переписном листе сразу после вопроса о национальности. С переписи 2010 г. эти два вопроса были разведены и поменялись местами: сначала спрашивают о языке, затем - о национальности. Но сама ментальность поменялась в малой степени.

Близкая мне позиция заключается в том, что “материнский язык - не обязательно родной, родной язык - не обязательно первый” [Вахтин 2001: 46]. Однако этой констатации недостаточно. Хотя демонтаж категории "родной язык” в силу эмоционально-политических причин затруднителен, возможна и необходима коррекция самой этой формулы в программе переписи населения, как мы и предложили выше. Скорректированный вопрос позволит ослабить связь категории языка с категорией национальности. Можно ожидать, что данные переписи в этом случае будут не в пользу нерусских языков. Зато будет более адекватным отражение реальной языковой ситуации в России, где сейчас официальные данные явно занижают степень языковой русификации, а точнее - языкового перехода представителей нерусской национальности (или их предков) на русский язык.

Чтобы этот вопрос дал объективные данные также и о распространении “родного двуязычия" среди россиян, необходимо поместить в пространстве ответа переписного листа не одну, а две свободные строки для заполнения. В этом случае полные билингвы смогут указать свои основные языковые компетенции, не совершая над собою насилие. Еще один языковой вопрос “Какими другими языками владеете?” позволит также выявить двуязычие и многоязычие среди граждан страны, включая этнических русских. Этот же вопрос даст ответы на знание как "языков народов России", так и иностранных языков. К сожалению, эти вопросы не выявляют ситуацию пользования языками: для этого нужно задавать другие вопросы, типа: “Ваш язык домашнего общения?” и “Каким языком пользуетесь на работе?” Так, в частности, формулируются переписные вопросы о языке в таких странах, как Австралия, Австрия, Беларусь, Венгрия, Индонезия, Канада.

Во многих странах, если не в переписи, то в социологических и других обследованиях такие вопросы задаются. Кстати, при проведении микропереписи населения 1994 г. такой вариант вопросов содержался и дал интересные результаты [Степанов 2018b: 89], но дальше дело так и не пошло: для статистиков это были дополнительные хлопоты и затраты, а заинтересованные ученые особо и не настаивали. Последние десятилетия ученые и практики привыкли (с некоторыми оговорками) по ответам на вопрос о родном языке конструировать, как им представлялось, реальную языковую ситуацию, включая распространение “национально-русского двуязычия". Корректировка категорий приведет к выявлению более точной ситуации и к более адекватной языковой политике (кстати, некорректным представляется и выражение “национально-русское двуязычие”).

Есть еще одна назревшая ревизия используемых в России языковых категорий, которая позволила бы не только улучшить смысловую составляющую

в переписях 1937 и 1939 гг., а также в послевоенной переписи 1959 г. упомянутые инструктивные указания были убраны. Итоги переписей о родном языке стали рассматривать как сведения о знании и распространении языков, а также так называемом национально-русском двуязычии. Этот инструментарий и стоявшая за ним методология позволяли учесть в основном только тот язык, который совпадал с национальностью опрашиваемого. 
языковой политики, но и привести наш язык в соответствие с языком мировой науки и политики. Речь идет о таком распространенном понятии, как “национальный язык”. Приведу цитату из введения к коллективному труду Института языкознания РАН, который является лидером среди исследовательских коллективов в области языковых процессов и языковой политики: “Исследование выявляет общую картину состояния и этнокультурного развития этносов России, то, как на их развитии отражаются общественные факторы, какова языковая компетенция различных этнических групп, насколько целесообразна и эффективна национальная политика государства, имеется ли положительная динамика в этнокультурном развитии народностей России, каковы перспективы их развития" [Языковая политика в контексте... 2015: 5]. И далее: “Нерешенной до сих пор остается проблема рационального распределения общественных функций между русским языком и национальными языками. В связи с происходящими в обществе изменениями возросла актуальность исследования причин, приводящих к реальной угрозе исчезновения национальных языков РФ, в частности миноритарных языков" [там же: 7].

В чем проблема с подобной позицией? Оставим в стороне ортодоксию по части дефиниции этнических общностей в трех вариантах в одном абзаце (этнос, этническая группа, народность), но обратим внимание на все то же склеивание языка и этничности как нормы и определение всех языков в России, кроме русского, как национальных. Хотя в мировой практике, даже в англоязычной “Википедии", в статье "National language” действительно отмечается многозначность данной категории, но в целом речь идет о понятии, которое синонимично категории “официальный язык” или “государственный язык”. В перечне национальных языков в разных странах читаем: “Из всех языков России русский язык является единственным официальным языком на национальном уровне. Вместе с русским есть еще 35 различных языков, которые считаются официальными языками в разных регионах России. Всего в России сегодня разговаривают на более чем 100 миноритарных языках". То, что А.Н. Биткеева называет национальными языками, в общепринятом формате будет называться миноритарными или этническими. Кстати, этими категориями российские социолингвисты также начали пользоваться, но только применительно к языкам “малочисленных народов" (национальности численностью меньше 50 тыс. человек).

Итак, в российском научном и политическом дискурсе такие распространенные в мире категории, как “родной язык” и “национальный язык” отданы в эксклюзивное владение этнических общностей, которые могут называться по-разному: нации, народы, народности, этносы, этнические группы. Эта этнизация языков на основе трактовки этничности с примордиальных позиций группизма $a^{4}$ рано или поздно должна быть подвергнута сомнению, ибо она расходится с мировым трендом в понимании современных языковых процессов и заключает в себе также конфликтогенные моменты.

В том же самом коллективном труде российских социолингвистов содержатся очерки о языковых ситуациях и языковой политике в других странах и регионах мира, которые заслуживают сравнительного анализа. Читатель обратит внимание, что в современных полиэтничных странах (точнее в культурно-сложных обществах) отсутствует обязательная связь “один на-

\footnotetext{
${ }^{4}$ Критику этногруппизма см. [Брубейкер 2012; Тишков 2003].
} 
род - один язык”. Каталанский язык в Испании - это не просто “национальный язык этноса каталонцев”, ибо в Испании сама категория этноса неприменима к местным регионально-историческим сообществам. Здесь каталонцы - это не этническая общность, а основное население провинции Каталония, а каталанский язык - это далеко не только язык каталонцев, но и других регионально-исторических сообществ этой страны (автономные сообщества Валенсия, Балеарские острова и др.). Каталаноязычные сообщества есть также во Франции и Италии. Похожая ситуация с канадскими франкофонами, которых невозможно назвать этносом или народностью, ибо, помимо части квебекцев, франкоязычные сообщества есть в Приморских провинциях Канады и в провинции Онтарио [Кожемякова 2017; Тишков 1984]. Именно о языковых сообществах, а не об этносах идет речь и в таких странах, как Бельгия, Швейцария, Франция и другие [Andersen, Carter 2016].

Этот подход к языку как к самостоятельной субстанции, а к его носителям совсем необязательно как к этнической группе, является ныне доминирующим, по крайней мере, в макрорегионе Евразии, за исключением некоторых стран бывшего СССР. Совсем неслучайно Европейская хартия региональных языков и языков национальных менышинств основывается именно на философии приоритета и самоценности самого языка, его статуса и перспектив, жестко не привязывая эту категорию социальной реальности к определенным группам, а тем более - к этнонациям и к “этнокультурному развитию народов России”.

Такой подход оправдывает себя, ибо не вызывает необходимости этнической мобилизации и не ведет к этнополитической напряженности вокруг языка. А языковые проблемы, которых в Европе много, при этом решаются, хотя и не столь легко и быстро. Заметим также, что, определяя субъект анализа и политической практики не как “этнос" или “народность", а как языковые сообшества, страны Европы уходят от проблемы "национальных меньшинств" в случаях, когда речь идет о языковой ситуации. Верховный комиссар ОБСЕ по делам национальных меньшинств Макс ван дер Стул однажды в ответе на мой вопрос, “почему в Вашу повестку не входят проблемы итальянского Тироля, французской Бретани или британского Ольстера?”, сказал следующее: “Это не в моей компетенции, ибо там не национальные менышинства, а языковые и религиозные менышинства. А вот в России - это национальные меньшинства”.

Таким образом, через узкоэтническую трактовку таких многозначных категорий, как “родной язык” и “национальный язык”, т.е. как язык определенной этнической общности, в России вопрос о языке вмонтирован и является частью именно этнической (у нас она называется "национальной”) политики, а также выступает центральным моментом программатики этнонационализма. Случай этот далеко не единичный, и этноязыковые конфликты и лингвистический национализм в мире известны хорошо, но считать это нормативной ситуацией было бы ошибкой. Недавние события в России подтверждают риски в “склейке” языка и этничности, особенно для гражданского нациестроительства.

\section{3. ЯЗЫК В СИСТЕМЕ НАЦИЕСТРОИТЕЛЬСТВА}

Одна из особенностей языковой ситуации в России - это наличие одного общенационального (государственного) языка, которым владеет 99,4\% населения (перепись 2010 г.), а не только этнические русские, которые составляют около $80 \%$ населения. Но русский язык - это единственный язык российской 
нации, который обладает официальным статусом. Еще около 40 языков наиболее многочисленных нерусских народов имеют государственный статус на уровне российских республик (последними официальными языками добавились в 2014 г. украинский и крымско-татарский в Крыму).

Это право предоставлено Конституцией РФ, хотя формулировка соответствующей статьи 68 носит самый общий характер: “Республики вправе устанавливать свои государственные языки, которые употребляются наряду с государственным языком Российской Федерации”. Несмотря на отсутствие прямого закрепления в Конституции права автономных округов устанавливать собственные государственные языки, округа собственными уставами и законами также могут устанавливать официальный статус языков проживающих в них этнических групп. Некоторые округа использовали эту возможность, как и некоторые республики, которые вместо государственного установили языки с официальным статусом (карельский, финский, вепский в Карелии), а некоторые вместе с государственным еще и предоставили статус официальных языкам малочисленных народов, проживающих на их территории (долганский, чукотский, юкагирский, эвенкийский, эвенкский в Якутии).

Примечательная коллизия в сфере языковой политики возникла после заседания в Йошкар-Оле в июле 2017 г. Совета при Президенте РФ по межнациональным отношениям, когда во вступительном слове В.В. Путина была обозначена проблема с обязательным изучением в школах ряда республик языка титульной национальности всеми жителями региона. Это вело к сокращению объема и к понижению уровня преподавания русского языка. После этого Минобрнауки и Генпрокуратуре России было поручено проверить ситуацию с преподаванием языков в российских республиках.

Напомним, что русский язык в обязательном порядке преподается во всех средних школах Российской Федерации. Все выпускники средних школ сдают в обязательном порядке Единый государственный экзамен (ЕГЭ) по русскому языку. В школах республик преподаются также государственные языки республик, а в некоторых - на этих языках ведется и преподавание в начальной или основной школах. Статус этих языков как предметов различался в зависимости от законодательства республики. Обязательное изучение государственного языка республики в школе вне зависимости от национальности обучающегося имело место в Башкортостане, Коми, Калмыкии (с 1 по 11 классы для "носителей языка”, с 1 по 9 классы по облегченной программе для остальных), Северной Осетии (для носителей обязательно, для не носителей обязательно, но по облегченной программе), Татарстане, Чувашии (с 1 по 9 классы). Обязательное изучение государственного языка республики в школе только для носителей было в Адыгее (русскоязычные имели право вместо него изучать адыгейскую литературу на русском языке), Ингушетии, Чеченской республике. Добровольным (как для носителей, так и для не носителей) было изучение государственного языка республики в школах Удмуртии и Республики Алтай.

Как понятно, под “носителями языка" имеются в виду лица соответствующей национальности, хотя вполне возможно и даже наверняка многие из них (в ряде случаев это большинство) не владеют и не пользуются этими языками. Так, например, большинство калмыков, бурят, мордвы, марийцев, алтайцев, хакасов не владеют языками своей национальности. Они, а точнее - еще их предки - перешли на русский язык. Значит, никакими “носителями языка" они не являются, и их родной язык - это русский язык. Однако местные за- 
коны в республиках предписывали этой категории населения обязательное изучение “национального языка". Вопрос этот представлялся настолько самоочевидным, что даже и не подвергался обсуждению во всей истории с преподаванием родных языков.

Дискуссии и напряженность вызвал вопрос, обязаны ли все обучающиеся жители республик изучать официальный язык данного субъекта федерации? Это касается прежде всего русского населения, а также представителей других “нетитульных" национальностей, которые могут составлять даже большинство населения и превосходить по численности “титульную” национальность. Так, например, в Башкортостане башкиры по численности уступают русским и татарам, но в этой республике с самого начала 1990-х годов было обязательно для всех изучение именно башкирского языка. Эта ситуация вызывала недовольство части учеников и родителей, направлявших многочисленные письма протеста и делавших публичные заявления. Одним из аргументов против этой практики было сокращение объема и качества изучения русского языка в школах республик, где значительная часть урочного времени уходила на изучение местных языков. Так, например, в Татарстане количество уроков русского и татарского языков было почти одинаковым, что могло привести к снижению уровня знаний русского языка.

Чем были недовольны часть учеников и их родители? Не только тем, что приходилось тратить школьное время на изучение языка, который мог быть довольно труден для усвоения и ничего, с точки зрения некоторых родителей, не добавлял для финальной школьной аттестации и для вступительных вузовских экзаменов. Даже освоив республиканский государственный язык и оставшись проживать в регионе, применять его в повседневной жизни особой нужды не было: все вокруг говорят на русском. Это, например, характерно для Северной Осетии и Мордовии, где подавляющее большинство жителей дома и на работе используют русский язык. Особое недовольство вызывала ситуация у тех, кого можно условно назвать “двойными меньшинствами”, т.е. у представителей нерусской национальности, проживающих как бы не в “своей” республике. Тогда ученик-ингуш, проживающий в Пригородном регионе Осетии, должен был обязательно изучать в школе осетинский, а не родной ингушский, а чуваш в Татарстане - изучать татарский, а не чувашский, и т.д. От этой части жителей республик и было больше всего жалоб. Но высказывали недовольство самые разные категории, в том числе и татары в Татарстане и башкиры в Башкирии, которые хотели бы иметь больше учебных часов для подготовки к ЕГЭ по русскому языку.

В 2017 г. Генпрокуратура проверила добровольность изучения языков народов РФ в регионах России и обнаружила нарушения во всех республиках. Но самое большое количество жалоб родителей школьников на принудительное обучение “титульному” языку и уменышение часов русского языка было зафиксировано в Татарстане, Башкортостане, Якутии и Чувашии. Минобразования РФ разработало методические указания, согласно которым изучение государственного языка республики должно быть добровольным, и более жестко отрегулировало образовательные стандарты, установив объемы изучения родного и государственного языков. Рассматриваемый в Государственной Думе законопроект предлагал установить принцип добровольности и факультативности в обучении республиканским языкам 
местными учащимися. Все эти действия вызвали ответную реакцию как со стороны части родителей, начавших более активно писать отказы от изучения местных языков, так и со стороны этнических активистов от республиканских властей. В Башкортостане и Татарстане прошли митинги в поддержку официальных языков и с требованием вернуть их обязательное преподавание в школах. Педагоги Чечни высказали мнение, что факультативное обучение не сможет обеспечить базового знания родного языка и что желательно изучение языка “титульной нации” всеми жителями Чечни. Президиум парламента Кабардино-Балкарии поддержал обращение Госсовета Татарстана о необходимости “сохранить право изучения родного языка в обязательной части школьной программы для всех народов России”. Общественная дискуссия по языковому вопросу возобновилась в Чувашии и Коми. Активисты из Северной Осетии обратились с просьбой к президенту В.В. Путину оставить осетинский язык обязательным для изучения в школах республики.

В августе 2018 г. вступил в силу принятый 25 июля Государственной Думой закон, дающий школьникам и их родителям право выбирать, какой язык будет изучать ребенок в качестве родного. При этом русский язык закон также включает в перечень для изучения в этом качестве. Предмет "Родной язык" остается в обязательной части учебных планов и не переходит в факультативную составляющую.

\section{4. ВОЗМОЖНЫЕ МОДЕЛИ В КОНТЕКСТЕ МИРОВОГО ОПЫТА}

Обзоры зарубежного опыта в данной области [Алпатов 2018; Бахнян 2018] выявляют большое число вариаций и поэтому мало что дают для прямого заимствования. Отметим некоторые общие моменты в тех моделях языковой политики, которые сегодня существуют в полиэтнических государствах и учет которых может быть полезен для российской науки и практики. В.М. Алпатов выделяет четыре модели языковой ситуации и политики. Первая - это один господствующий на всей территории государства язык (с государственным статусом или без него) и отсутствие государственной поддержки языков меньшинств. Из крупных государств это главным образом англоязычные страны США и Великобритания, а также Япония и Турция. Данный вариант жесткой (ассимиляционной) политики проводит ряд стран бывшего СССР (кроме России и Беларуси). Украина и Казахстан также тяготеют к данной модели из-за ужесточений в отношении русского языка в последние годы. Эта модель обусловлена как исторической и этнодемографической ситуацией, так и политикой становления национальной государственности. Вторая модель - равноправное официальное многоязычие (два языка в Канаде, Бельгии и Финляндии, четыре - в Швейцарии). Третья модель - один доминирующий (обычно со статусом общегосударственного) язык при признании и господдержке других языков (на национальном или региональном уровнях). Это - многие страны Европы (например, Италия, Испания, Франция) и англоязычные страны Австралия и Новая Зеландия, а также Китай. И четвертая модель - модель языкового плюрализма без доминирующего языка или языка бывшей колониальной метрополии в этом качестве (большинство стран Азии и Африки). К той модели тяготеют Индия и Индонезия [Алпатов 2018: 24].

Автор этой классификации считает, что в России языковая политика во многом носит стихийный характер, и она колеблется между первой и третьей 
моделями [там же: 30] На наш взгляд, ассимиляционная модель не подходит для современной России, как и для оценки советского языкового строительства. Более того, именно европейские страны во многом заимствовали советский опыт поддержки и развития миноритарных языков, для 50 из которых в СССР была создана собственная письменность. Если придерживаться данной классификации, то к российской ситуации подходит именно третья модель. Однако всякая модель заключает в себе упрощение, ибо реальные практики более разнообразны, а политические решения более сложны.

Так, например, только в одной испанской провинции - Стране Басков официально действуют четыре лингвистических модели языковой политики в системе образования (с начала 1980-х годов баскский язык официальный наряду с испанским языком). Модель “А”: преподавание на испанском с четырьмя часами в неделю баскского языка (это всего 7\% учащихся, главным образом из иммигрантских семей); модель “В” предполагает использование двух языков изучения и преподавания, но большинство предметов преподаются на испанском (около 30\% учащихся); при модели “D” почти все предметы преподаются на баскском языке, за исключением испанского языка и литературы, которым отведено четыре часа в неделю (около $63 \%$ учащихся). Модель "Х" (исключительно испанский язык) позволена только частным школам и освобождение от изучения баскского языка позволено только для детей с коротким сроком проживания в провинции [Мустафина 2010]. Эти данные относятся к 2006 г., а наши наблюдения в этой провинции в 2017 г. свидетельствуют о росте числа учеников, обучающихся на баскском языке, и о превращении этого языка в элитарный по сравнению с испанским. Однако растущее число полных билингвов из числа школьных выпускников не изменило положение с доминированием испанского в общественной жизни региона и его большей престижности. Зато создается ситуация недовостребованности тех, кто считает баскский язык своим первым языком и желал бы пользоваться им и на работе. Эта ситуация напоминает положение в канадском Квебеке, где франкофоны длительной политической борьбой и высокой степенью языковой лояльности обеспечили для своего языка приоритетные позиции, но только на уровне одной провинции (не считая Монреаля), а остальная Канада так и не стала двуязычной [Кожемякова 2017: 360; Тишков 1984].

Все это говорит о том, что в сфере языковой политики можно вести речь о равноправии языков, но не об их равенстве, ибо доминирующий в государстве язык, да еще и с мировым статусом, всегда будет иметь преимущества на так называемом языковом рынке. А поскольку государство также заинтересовано в том, чтобы граждане владели общим языком для обеспечения национальной солидарности и для более эффективного общественного управления, то официальный (государственный, национальный) язык всегда будет иметь еще и дополнительные преимущества. Тем самым в системе современного нациестроительства наиболее оптимальной выглядит следующая формула, в рамках которой возможны разные модели в зависимости от ресурсов, которыми обладают языки в своем соперничающем взаимодействии. Эту формулу попытался сформулировать один из современных социолингвистов: "Перед всеми полиэтническими и многоязычными государствами в наступившем XXI в. встает стратегическая проблема выработки особых конвергентных моделей развития языковой политики, во многом определяемые общей стратегией внутренней языковой политики, 
проводимой правительствами этих государств - языковой политики плюрализма, демократизации и интеграции или ассимиляции” [Бахнян 2018: 103].

Мы бы предпочли выразиться несколько иначе. В языковой сфере как части неубывающего культурного многообразия современных государств следует обеспечивать общенациональное единство не на путях монокультурности (моноязычия), понимая единство как “единственное”, а на путях утверждения гражданской идентичности и патриотизма через политику признания и поддержки культурной сложности, в которой сочетаются общенациональные культурные системы, включая общий язык, и этнокультурное многообразие, включая миноритарные языки. Это признанное многообразие и есть то самое единство, в котором нуждаются и которое ищут современные культурно-сложные общества и государства.

DOI: $10.17976 /$ jpps/2019.03.08

\title{
LANGUAGE SITUATION AND LANGUAGE POLICY IN RUSSIA (REVISING CATEGORIES AND PRACTICES)
}

\author{
V.A. Tishkov ${ }^{1,2}$ \\ ${ }^{1}$ Institute of Ethnology and Anthropology, Russian Academy of Sciences. Moscow, Russia \\ ${ }^{2}$ Russian State University for the Humanities. Moscow, Russia
}

TISHKOV, Valery Aleksandrovich, Dr. Sci. (Hist.), Professor, Academician of RAS, Research Director, Institute of Ethnology and Anthropology, Russian Academy of Sciences; Research Centre for Social Anthropology, Russian State University for the Humanities, email: valerytishkov@mail.ru

Tishkov V.A. Language Situation and Language Policy in Russia (Revising Categories and Practices). - Polis. Political Studies. 2019. No. 3. P. 127-144. (In Russ.) https://doi.org/10.17976/jpps/2019.03.08

Acknowledgements. The study was carried out at the expense of a grant from the Russian Science Foundation (project No. 14-18-03090).

Received: 08.12.2018. Accepted: 19.01.2019

\begin{abstract}
This article revises existing Russian practices of categorization and procedures in the evaluation of the language situations and the exercising of the language policy. In the center of its analysis are interactions of language and ethnicity, and language and state politics, especially census taking procedures. The revision of such categories as "native language", "mother tongue", or "national language" are suggested in favor of more sensitive, situational, multiple approaches which reflect factors of rational choice, "language market", structural prescriptions, and language repertoire in culturallycomplex societies, as well as of historical dynamic language processes. The author argues against rigid connections between language and ethnicity and raises the issue of the rights of linguistic communities, and the support of languages as independent values in a culture of human communications. In the realm of language policy, the article considers language issues in contemporary nation building as well as a balance between official (national) language(s) and ethnic (minority) languages in the public life of countries such as the Russian Federation.
\end{abstract}

Keywords: Russia, native language, mother tongue, official (national) language, language situation, language policy, ethnicity, population census, nation-building, language rights, school education.

\section{References}

Andersen J.T., Carter P.M. 2016. Languages In The World: How History, Culture, and Politics Shape Language. Oxford, UK: WILEY Blackwell.

Chevalier J.F. 2005. Language Policy in the Russian Federation: Russian as the "State" Language. $-A b$ Imperio. No. 1. P. 285-303. https://doi.org/10.1353/imp.2005.0030

Gorenburg D.P. 2003. Minority Ethnic Mobilization in the Russian Federation. Cambridge, UK: Cambridge University Press. 
Gorham M. 2014. After Newspeak: Language, Culture and Politics in Russia from Gorbachev to Putin. Ithaca, NY: Cornell University Press.

Grenoble L.A. 2003. Language Policy in the Soviet Union. Dordrecht: Kluwer Academic Publishers.

Hirsch F. 2005. Empire of Nations: Ethnographic Knowledge and the Making of the Soviet Union. Ithaca: Cornell University Press.

Laitin D. 1998. Identity in Formation: The Russian-Speaking Populations in the Near Abroad. Ithaca: Cornell University Press.

Myles J.F. 2010. Bourdieu, Language and the Media. Basingstoke: Palgrave Macmillan.

Swartz D. 1998. Culture \& Power: The Sociology of Pierre Bourdieu. Chicago: University of Chicago Press.

Alpatov V.M. 2018. Yazykovaya politika v sovremennom mire [Language Policy in the Modern World]. Yazykovoe edinstvo i yazykovoe raznoobrazie v polietnicheskom gosudarstve. Mezhdunarodnaya konferentsiya (Moskva, 14-17 noyabrya 2018 g.): doklady i soobshcheniya [Linguistic Unity and Linguistic Diversity in a Multi-Ethnic State. International Conference (Moscow, 14-17 November 2018): reports and presentations. Ed. by A.N. Bitkeeva, M.A. Goryacheva]. Moscow: Iazyki narodov mira Publ. P. 24-33. (In Russ.)

Bakhnian K.V. 2018. Sotsiolingvisticheskaia strategiia i modeli iazykovoi politiki polietnicheskikh gosudarstv [Sociolinguistic Strategy and Models of Language Policy of Multi-Ethnic States]. - Yazykovoe edinstvo i yazykovoe raznoobrazie v polietnicheskom gosudarstve. Mezhdunarodnaya konferentsiya (Moskva, 14-17 noyabrya 2018 g.): doklady i soobshcheniya [Linguistic Unity and Linguistic Diversity in a Multi-Ethnic State. International Conference (Moscow, 14-17 November 2018): reports and presentations. Ed. by A.N. Bitkeeva, M.A. Goryacheva]. Moscow: Iazyki narodov mira Publ. P. 95-105. (In Russ.)

Bourdieu P. 2005. O proizvodstve i vosproizvodstve legitimnogo yazyka [About the Production and Reproduction of Legitimate Language]. - Otechestvennye zapiski. No. 2. P. 10-21. (In Russ.)

Brubaker R. 2012. Ethnicity Without Groups. (Russ. ed.: Brubaker R. Etnichnost' bez grupp. Moscow: HSE Publishers).

Chizhikova L.N. 1988. Russko-ukrainskoe pogranich'e. Istoriia i sud'by traditsionno-bytovoi kul'tury [The Russian-Ukrainian Border. The History and Fate of Traditional and Everyday Culture]. Moscow: Nauka. 256 p. (In Russ.)

Evropeiskaya khartiya regional'nykh yazykov ili yazykov men'shinstv v Rossiiskoi Federatsii [European Charter for Regional or Minority Languages in the Russian Federation]. 2012. Ed. by A.S. Kozhemyako, S.V. Sokolovskiy. Moscow: Ministry of Regional Development, Council of Europe. 175 p. (In Russ.)

Guboglo M.N. 1998. Iazyki etnicheskoi mobilizatsii [Languages of Ethnic Mobilization]. Moscow: Iazyki slavianskoi kul'tury. 813 p. (In Russ.)

Guboglo M.N. 2018. Kto otnial rodnoi iazyk? [Who Took the Mother Tongue?]. - Guboglo M.N. Sochineniia v $10 \mathrm{tt}$. Etnichnost' [Works in 10 vol. Vol. 1. Ethnicity]. Moscow: IEA RAN. (In Russ.)

Guboglo M.N., Bromlei Y.V. 1984. Sovremennye etnoiazykovye protsessy v SSSR: osnovnye faktory i tendentsii razvitiia natsional'no-russkogo dvuiazychiia [Modern Ethno-Linguistic Processes in the USSR: the Main Factors and Trends in the Development of National Russian Bilingualism]. Moscow: Nauka Publ.

Iazykovaia politika v kontekste sovremennykh iazykovykh protsessov [Language Policy in the Context of Modern Language Processes]. 2015. Ed. by A.N. Bitkeeva. Moscow: Azbukovnik. 472 p. (In Russ.)

Iazykovaia politika, konflikty i soglasie [Language Policy, Conflict and Consent]. 2017. Ed. by S.V. Sokolovskiy, E.I. Filippova. Moscow: IEA RAS. 272 p. (In Russ.)

Ibragimov G.H., Zachesov K.Ya. 1990. O ponyatii "rodnoi yazyk" [On the Concept of "Native Language"]. - Russkii yazyk v natsional'noi shkole. No. 8. P. 10-15. (In Russ.)

Islamshina T.G. 1996. Etnicheskie tsennosti polietnichnogo obshchestva. Sotsiologicheskii ocherk [Ethnic Values of Polyethnic Society. Sociological Essay]. Kazan': Kazanskii gosudarstvennyi tekhnicheskii universitet. 247 p. (In Russ.)

Khabenskaya E. 2004. "Native Language" as an Ethnic Symbol. - Kazan Federalist. No. 1(9). P. 91-92. (In Russ.) URL: http://www.kazanfed.ru/publications/kazanfederalist/n9/7/ (accessed 01.03 2019)

Kostomarov V.G. 1991. Once Again about the Concept of "Native Language". - Russkii yazyk v SSSR. No. 1. P. 9-15. (In Russ.)

Kozhemiakova V.A. 2017. Osobennosti iazykovoi politiki v Kanade [Features of Language Policy in Canada]. - Reshenie natsional'no-iazykovykh voprosov kak faktor ukrepleniia natsional'noi bezopasnosti Rossii [Solution of National Language Issues as a Factor of Strengthening National Security of Russia]. Ed. by E.P. Chelysheva. Moscow: Azbukovnik. P. 360-381.

Kozlov V.I. 1995. Iazyk [Language]. - Etnicheskie i etnosotsial'nye kategorii. Svod etnograficheskikh poniatii i terminov [Ethnic and Ethno-Social Categories. Code of Ethnographic Pontius and Terms]. Ed. by V.I. Kozlov. Vol. 6. Moscow: Nauka. (In Russ.) 
Kul'turnaia slozhnost' sovremennykh natsii [The Cultural Complexity of Modern Nations]. 2016. Ed. by V.A. Tishkov, E.I. Filippova. Moscow: Politicheskaia entsiklopediia. 384 p. (In Russ.)

Mamardashvili M. 1992. Laws of Inakonemyslie. - Zdes' i teper'. No. 1. P. 85-93. (In Russ.)

Mustafina D.N. 2010. The Main Directions of Language Policy in The Regions of European States (the Experience of Autonomies in Spain). - Vestnik Chelyabinskogo gosudarstvennogo universiteta. Filologiya. Iskusstvovedenie. No. 29 (210). Vol. 47. P. 107-109. (In Russ.)

Reshenie natsional'no-iazykovykh voprosov kak faktor ukrepleniia natsional'noi bezopasnosti Rossii [The Solution of National-Language Issues as a Factor in Strengthening the National Security of Russia. 2017. Ed. by E.P. Chelysheva]. Moscow: Azbukovnik Publishing Center. 656 p. (In Russ.)

Shakhnarovich A.M. 1999. Detskaia rech'v zerkale psikholingvistiki. Leksika. Semantika. Grammatika [Children's Speech in the Mirror of Psycholinguistics. Vocabulary. Semantics. Grammar]. Moscow: Institut iazykoznaniia RAN.165 p. (In Russ.)

Sovremennye etnicheskie protsessy v SSSR [Modern Ethnic Processes in the USSR]. 1975. Ed. by Y.V. Bromlei. Moscow: Nauka. 545 p. (In Russ.)

Stepanov V.V. 2018. O konfliktnom vospriiatii kul'turnykh razlichii [On the Conflict Perception of Cultural Differences on the Conflict Perception of Cultural Differences]. - Gosudarstvennaia natsional'naia politika Rossii: ekspertnoe mnenie [State National Policy of Russia: Expert Opinion Ed. by V.V. Stepanov, A.V. Chernykh]. Moscow: IEA RAN. P. 15-25. (In Russ.)

Stepanov V.V. 2018. Iazykovaia situatsiia v Rossii [Language Situation in Russia]. - Etnicheskoe i religioznoe mnogoobrazie Rossii [Ethnic and Religious Diversity of Russia. Ed. by V.A. Tishkov, V.V. Stepanov. 2nd ed.]. Moscow: IEA RAN. P. 89-106. (In Russ.)

Tishkov V.A. 1984. Anglo-franzusckoe dvuyazychie v Kanade [English-French Bilingualism in Canada]. Soviet Ethnography. No. 4. P. 47-56. (In Russ.)

Tishkov V.A. 2003. Rekviem po etnosu. Issledovaniia po sotsial'no-kul'turnoi antropologii [Requiem for Ethnos. Research in Social and Cultural Anthropology]. Moscow: Nauka. 544 p. (In Russ.)

Tishkov V.A. 2013. Rossiiskii narod. Istoriia i smysl natsional'nogo samosoznaniia [Russian People. History and Meaning of National Identity]. Moscow: Nauka Publ. 649 p. (In Russ.)

Vakhtin N.B. 2001. Iazyki narodov Severa v XXveke. Ocherki iazykovogo sdviga [Languages of the Peoples of the North in the $20^{\text {th }}$ Century. Language Shift Essays]. St. Petersburg: Dmitrii Bulanin. 338 p. (In Russ.)

Vakhtin N.B. 2018. Vliianie idei "dvuiazychiia kak normy" na razvitie lingvistiki [The Influence of the Idea of "Bilingualism as a Norm" on the Development of Linguistics]. - Yazykovoe edinstvo i yazykovoe raznoobrazie v polietnicheskom gosudarstve. Mezhdunarodnaya konferentsiya (Moskva, 14-17 noyabrya 2018g.): doklady $i$ soobshcheniya [Linguistic Unity and Linguistic Diversity in a Multi-Ethnic State. International Conference (Moscow, 14-17 November 2018): reports and presentations. Ed. by A.N. Bitkeeva, M.A. Goryacheva]. Moscow: Iazyki narodov mira Publ.P. 38-43. (In Russ.)

Yazykovaya politika, konflikty i soglasie [Language Policy, Conflict and Consent]. 2017. Ed. by S.V. Sokolovskiy, E.I. Filippova. Moscow: IEA RAS. 272 p. (In Russ.)

Yazykovaya politika v kontekste sovremennyk yazykovykh protsessov [Language Policy in the Context of Modern Language Processes]. 2015. Ed. by A.N. Bitkeeva. Moscow: Izdatel'skii tsentr “Azbukovnik”. 472 p. (In Russ.)

Yazykovoe edinstvo i yazykovoe raznoobrazie v polietnicheskom gosudarstve. Mezhdunarodnaya konferentsiya (Moskva, 14-17 noyabrya 2018 g.): doklady i soobshcheniya [Linguistic Unity and Linguistic Diversity in a Multi-Ethnic State. International Conference (Moscow, 14-17 November 2018): reports and presentations. Ed. by A.N. Bitkeeva, M.A. Goryacheva]. Moscow: Iazyki narodov mira Publ. (In Russ.)

\section{Литература на русском языке}

Алпатов В.М. 2018. Языковая политика в современном мире. - Языковое единство и языковое разнообразие в полиэтническом государстве. Международная конференция (Москва, 14-17 ноября 2018 г.): доклады и сообщения. Отв. ред. А.Н. Биткеева, М.А. Горячева. М.: Языки народов мира. С. 24-33.

Бахнян К.В. 2018. Социолингвистическая стратегия и модели языковой политики полиэтнических государств. - Языковое единство и языковое разнообразие в полиэтническом государстве. Международная конференция (Москва, 14-17 ноября 2018 г.): доклады и сообщения. Отв. ред. А.Н. Биткеева, М.А. Горячева. М.: Языки народов мира. С. 95-105.

Брубейкер Р. 2012. Этничность без групп. М.: Издательский дом ВШЭ. 408 с.

Бурдьё П. 2005. О производстве и воспроизводстве легитимного языка. - Отечественные записки. № 2. С. 10-21

Вахтин Н.Б. 2001. Языки народов Севера в ХХ веке. Очерки языкового сдвига. СПб.: Дмитрий Буланин. 338 с. 
Вахтин Н.Б. 2018. Влияние идеи “двуязычия как нормы” на развитие лингвистики. - Языковое единство Языковое единство и языковое разнообразие в полиэтническом государстве. Международная конференция (Москва, 14-17 ноября 2018 г.): доклады и сообщения. Отв. ред. А.Н. Биткеева, М.А. Горячева. М.: Языки народов мира. С. 38-43.

Губогло М.Н., Бромлей Ю.В. 1984. Современные этноязыковые процессы в СССР: основные факторы и тенденции развития национально-русского двуязычия. М.: Наука.

Губогло М.Н. 1998. Языки этнической мобилизации. М.: Языки славянской культуры. 813 с.

Губогло М.Н. 2018. Кто отнял родной язык? - Губогло М.Н. Сочинения в 10 mm. Этничность. Т. 1. М: ИЭА РАН.

Европейская хартия региональных языков или языков меньшинств в Российской Федерации. 2012. Отв. ред. А.С. Кожемяков, С.В. Соколовский. М.: Минрегион РФ, Совет Европы. 175 с.

Ибрагимов Г.Х., Зачесов К.Я. 1990. О понятии “родной язык”. - Русский язык в национальной школе. № 8. С. 10-15.

Исламшина Т.Г. 1996. Этнические ценности полиэтничного общества. Социологический очерк. Казань: Казанский государственный технический университет. 248 с.

Кожемякова В.А. 2017. Особенности языковой политики в Канаде. - Решение национально-языковых вопросов как фактор укрепления национальной безопасности России. Под. ред. Е.П. Челышева. М.: Азбуковник” С. 360-381.

Козлов В.И. 1995. Язык. - Этнические и этносоциальные категории. Свод этнографических понятий и терминов. Вып. 6. Под. ред. В.И. Козлова. М.: Наука.

Костомаров В.Г. 1991. Еще раз о понятии “родной язык". - Русский язык в СССР. № 1. С. 9-15.

Культурная сложность современных наций. 2016. Отв. ред. В.А. Тишков, Е.И. Филиппова. М.: Политическая энциклопедия. 384 с.

Мамардашвили М. 1992. Законы инаконемыслия. - Здесь и теперь. № 1. С. 85-93.

Мустафина Д.Н. 2010. Основные направления языковой политики в регионах европейских государств (на примере автономий в Испании). - Вестник Челябинского государственного университета. № 29 (210). Филология. Искусствоведение. Вып. 47. С. 107-109.

Решение национально-языковых вопросов как фактор укрепления национальной безопасности России. 2017. Под. ред. Е.П. Челышева. М.: Издательский центр “Азбуковник”. 656 с.

Современные этнические процессы в СССР. 1975. Отв. ред. Ю.В. Бромлей. М.: Наука. 545 с.

Степанов В.В. 2018а. О конфликтном восприятии культурных различий. С. 15-25. - Государственная национальная политика России: экспертное мнение. Отв. ред. В.В. Степанов, А.В. Черных. Москва: ИЭА РАН. 380 с.

Степанов В.В. 2018b. Языковая ситуация в России. - Этническое и религиозное многообразие России. Под. ред. В.А. Тишкова, В.В. Степанова. Изд. 2-е. С. 89-106.

Тишков В.А. 1984. Англо-французское двуязычие в Канаде. - Советская этнография. № 4. С. 47-56.

Тишков В.А. 2003. Реквием по этносу. Исследования по социально-культурной антропологии. М.: Наука. 544 с.

Тишков В.А. 2013. Российский народ. История и смысл национального самосознания. М.: Наука. 649 с.

Хабенская Е. 2004. "Родной язык” как этнический символ. - Казанский федералист. № 1(9). С. 91-92. URL: http://www.kazanfed.ru/publications/kazanfederalist/n9/7/ (accessed 01.03 2019).

Чижикова Л.Н. 1988. Русско-украинское пограничье. История и судьбы традиционно-бытовой культуры. М.: Наука. 256 с.

Шахнарович А.М. 1999. Детская речь в зеркале психолингвистики. Лексика. Семантика. Грамматика. М.: Институт языкознания РАН. 165 с.

Этническое и религиозное многообразие России. 2018. Под ред. В.А. Тишкова, В.В. Степанова. Изд. 2-е. М.: ИЭА РАН. 561.

Язык и общество. Энциклопедия. Гл. ред. В.Ю. Михальченко. 2016. М.: Издательский центр “Азбуковник".

Языковая политика в контексте современных языковых процессов. 2015. Под. ред. А.Н. Биткеевой. М.: Издательский центр “Азбуковник”. 472 с.

Языковая политика, конфликты и согласие. 2017. Отв. ред. С.В. Соколовский, Е.И. Филиппова. М.: ИЭА РАН. 272 с.

Языковое единство и языковое разнообразие в полиэтническом государстве. Международная конференция (Москва, 14-17 ноября 2018): доклады и сообщения. Отв. ред. А.Н. Биткеева, М.А. Горячева. 2018. М.: Языки народов мира. 750 с. 